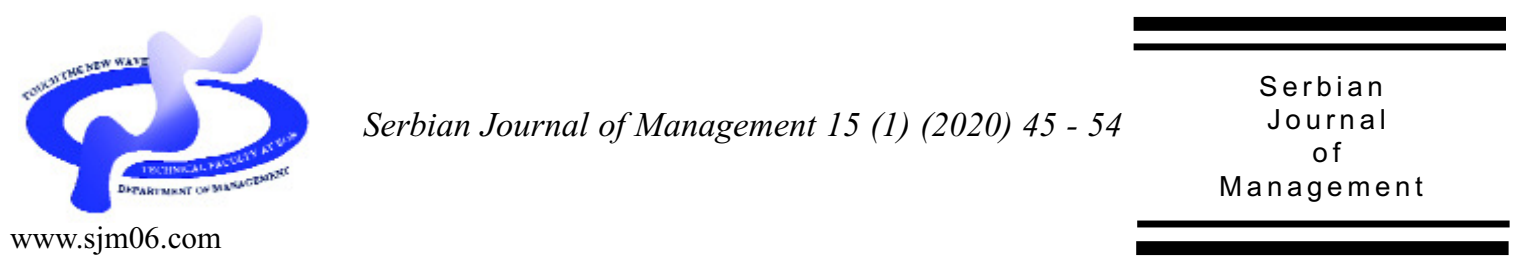

\title{
DOES STOCK MARKET-BASED FINANCIAL DEVELOPMENT PROMOTES ECONOMIC GROWTH IN EMERGING MARKETS? NEW EVIDENCE FROM NIGERIA
}

\author{
Solomon Prince Nathaniel*, Joseph Ayoola Omojolaibi and \\ Chikaodili Josephine Ezeh
}

\author{
University of Lagos,Department of Economics, Akoka, Nigeria
}

(Received 04 June 2018; accepted 08 October 2018)

\begin{abstract}
This study examines the effect of stock market development on economic growth in Nigeria. The study spans the period 1980-2016. It employs the ARDL approach to cointegration. Evidence from the study indicates that stock market development promotes economic growth in the short-run, but in the long-run, the growth impact of stock market development is not significant. The growth impact of market capitalization, value of shares traded, and market turnover ratio are all significant in the short run while that of trade openness is not. Meanwhile, trade openness is the only variable that significantly impacts economic growth in the long-run. The Bounds test for cointegration reveals a long-run relationship among the variables. All the variables, apart from trade openness, are positively correlated with economic growth. The results of this study imply that stock market development plays a major role in economic growth in Nigeria. It is recommended that the regulatory authority enacts policies that will promote liquidity, stability and accountability in the stock market which could possibly perpetuate economic growth in Nigeria.
\end{abstract}

Keywords: stock market development, economic growth, time series analysis, block exogeneity Wald tests, ARDL

\section{INTRODUCTION}

The capital market is an important facilitator of economic growth. The capital market is a sub-set of the financial system that serves as an engine of growth in modern economies. Donwa \& Odia (2010) identified the capital market as an institution that contributes to the socio-economic growth and development of emerging economies. Apart from the judicious mobilization of idle savings into productive use, the stock market creates an avenue for foreign investment and

\footnotetext{
*Corresponding author: nathaniel_solomon21@yahoo.com
}

DOI: $10.5937 /$ sjm15-17704 
the influx of foreign capital for developing projects that increase the welfare of citizens (Owolabi \& Motilewa, 2015). Despite the size and illiquid nature of stock market, its continued existence and development could have important implications for economic activity (Alajekwu \& Achugbu, 2012).

The big question begging for answers remains; can stock market financial development vis-a-vis stock market liquidity precipitate or translate to economic growth in Nigeria? This question has been greeted with mixed results from various studies carried out in this direction as revealed in the literature. In the case of Nigeria, for instance, Ewah et al. (2009) concluded that the stock market in Nigeria has not contributed meaningfully to the economic growth of Nigeria. Also, while Adam and Sanni (2005) discovered one-way causality between economic growth and market capitalization in Nigeria, Anigbogu and Nduka (2014) discovered a two-way causality which is the direct opposite of the former. Again, while some studies are in support of negative relations in the liquidity-growth nexus (Alajekwu \& Achugbu, 2012), others are in support of positive relations in the liquiditygrowth nexus (Ogunmuyiwa \& Ekone, 2010). These divergences in empirical results call for further investigation on the effect of stock market development on economic growth in Nigeria. This was the motivation for this study. Most studies, especially in emerging economies, only considered the internal factors like: market capitalization, the value of shares traded, market turnover ratio and all shares index without paying attention to external influence that could emanate from openness to trade. This study therefore adds to the existing literature by controlling for the influence of trade openness. Alajekwu et al. (2013) carried out a similar study under the simple OLS framework which would rather not give a robust result when compared to the ARDL cointergration technique. On the strength of the above, this study attempts to dig out the empirical evidence in the context of Nigeria regarding the effect of stock market development on economic growth, resolve the liquidity-growth nexus puzzle and examine the direction of causality, if any, between stock market development and economic growth.

The rest of the paper is organized as follows: In section 2, we highlight the empirical review of the study. Section 3 briefly describes the variables, the methodology adopted and model specification. Section 4 contains the empirical findings and interpretation of empirical results. Section 5 presents summary remark and policy recommendations.

\section{LITERATURE REVIEW}

Based on the importance attached to the stock markets all over the world, numerous studies have been conducted on the effect of stock market development on economic growth both in Nigeria and other countries of the world.

Manasseh et al. (2018) examined the causal effect of stock market development, financial sector reforms and economic growth in Nigeria. A Vector Autoregressive and Error Correction Model were used for the investigation. The study revealed a bidirectional causality between stock market development and economic growth and, financial sector reforms and economic growth. Pan and Mishra (2018) used the ARDL to explore the interplay between stock 
market and real economy investigate the various channels through which financial markets drive economic growth in China. The study found that Global Financial Crises had a significant impact on both China's real sector and financial sector. Okoro (2017) investigated the effect of selected macroeconomic factors on stock market performance in Nigeria as represented by Nigeria Stock Exchange. The Ordinary Least Squares regression technique was employed for data analysis. From the findings of the study, stock prices are not a leading indicator of macroeconomic variables in Nigeria and movements in stock prices cannot actually be explained by macroeconomic factors. Magweva and Mashamba (2016) examined the relationship between stock market and economic growth in Zimbabwe between 1989 and 2014. The VECM results revealed long run negative relationship between stock market development and economic growth, whereas the short run coefficients were insignificant. Kajurová and Rozmahel (2016) explored the relationship between stock market development and economic growth in the European Union countries using the vector error correction model and the Granger causality test. They discovered that economic growth impacts on stock market development in the long-run in the sample of the Euro area member countries. In the short-run, stock market development was found to impact on economic growth in the non-Euro area countries.

Ogunrinola and Motilewa (2015) examined the impact of stock market liquidity on economic growth of Nigeria between the years 1980 to 2012 . The study found, surprisingly, that stock market liquidity was not a statistically significant variable that could promote economic growth in Nigeria in the period covered by the study. Gazdar and Cherif (2015) examined the role institution can play in the finance-growth nexus with a special focus on MENA countries. From their findings, institutional quality reduces the negative effect of financial development on economic growth. Also, financial development can only promote growth within a strong institutional framework. Pradhan et al. (2015) investigated the impact of oil prices, stock market development and other macroeconomic variables on economic growth in a panel of twenty ASEAN countries from 1961 to 2012. Using a panel vector autoregressive model for testing the Granger causality, their result showed a bidirectional causality between stock market development and economic growth. However, various studies have investigated the relationship between stock market development and economic growth in Nigeria and concluded that the relationship is positive (see Osuala et al., 2013; Owolabi \& Ajayi, 2013; Anigbogu \& Nduka, 2014; Okonkwo et al., 2014).

Hence, given these divergent views and results, the debate in the literature and empirics on the link between stock market development, liquidity and the economy remains inconclusive, thus justifying the need for a closer look at the Nigerian case. Therefore, more research in Nigeria would be of help to academics and policy-makers alike.

\section{DATA CONSTRUCTION AND METHODOLOGICAL DISCUSSION}

\subsection{Data}

Annual time series data on Gross Domestic Product (GDP), market 
capitalization, the total value of stocks traded, and the turnover ratio of stocks traded covering the period 1980-2016 are employed. Stock market capitalization represents the size of the stock market. It is the total value of the listed stock. The total value of stocks traded and turnover ratio of stocks traded variables represent liquidity of the stock market. It is the ratio of total value of stock traded to GDP. Market turnover ratio is the ratio of total value of shares traded on the stock market to market capitalization while trade openness is the ratio of trade to GDP. The annual time series data were obtained from the Nigeria Stock Exchange Annual Reports and Account of various years; and the Central Bank of Nigeria Statistical Bulletin (2017).

\subsection{Methodology}

The model adopted for this study was based on the improvement suggested by Enekwe et al. (2016). To model the relationship among our variables the paper adopts the Autoregressive Distributed Lag (ARDL) bounds test to cointegration of Pesaran et al. (2001). As such we begin by modelling the functional relationship among the variables. This functional relationship is shown in Equation (1) where $\mathrm{GDP}_{t}$ represent economic growth, $\mathrm{MCP}_{\mathrm{t}}$ denotes market capitalization ratio, $\mathrm{VST}_{\mathrm{t}}$ denotes value of shares traded, $\mathrm{MTR}_{\mathrm{t}}$ is the market turnover ratio, and $\mathrm{OPEN}_{\mathrm{t}}$ represent trade openness.

$$
G D P_{t}=f\left(M C P_{t}, V S T_{t}, M T R_{t}, O P E N_{t}\right)
$$

We modify and developed a log linear econometric model to include the drift parameter and the stochastic error term. The econometric relationship is shown in Equation (2) :

$$
\begin{aligned}
& \ln G D P_{t}=\omega_{t}+\omega_{1} \ln M C P_{t}+\omega_{2} \ln V S T_{t} \\
& +\omega_{3} \ln M T R_{t}+\omega_{4} \ln O P E N_{t}
\end{aligned}
$$

Following the principles of Pesaran et al. (2001), the econometric model is further decomposed into dynamic unrestricted error correction model (UECM), where economic growth was expressed as a function of its previous lag along with level and first difference of other explanatory variables in the model. The dynamic ARDL is constructed in Equation (3) :

$$
\begin{aligned}
& \Delta \ln G D P_{t}=\Psi_{0}+\sum_{i=1}^{n} \Psi_{1 i} \Delta \ln G D P_{t-1} \\
& +\sum_{i=0}^{n} \Psi_{2 i} \Delta \ln M C P_{t-1}+\sum_{i=0}^{n} \Psi_{3 i} \Delta \ln V S T_{t-1} \\
& +\sum_{i=0}^{n} \Psi_{4 i} \Delta \ln M T R_{t-1}+\sum_{i=0}^{n} \Psi_{5 i} \Delta \ln O P E N_{t-1} \\
& +\pi_{0}+\pi_{1} \ln G D P_{t-1}+\pi_{2} \ln M C P_{t-1} \\
& +\pi_{3} \ln V S T_{t-1}+\pi_{4} \ln M T R_{t-1} \\
& +\pi_{5} \ln O P E N_{t-1}+\varepsilon_{t}
\end{aligned}
$$

The error correction model is developed in Equation (4) in order to determine the speed of convergence when there is deviation from long-run equilibrium resulting from short term shocks.

$$
\begin{aligned}
& \Delta \ln G D P_{t}=\partial_{0}+\sum_{i=1}^{n} \beta \partial_{1 i} \Delta \ln G D P_{t-1} \\
& +\sum_{i=1}^{n} \partial_{2 i} \Delta \ln M C P_{t-1}+\sum_{i=1}^{n} \partial_{3 i} \Delta \ln V S T_{t-1} \\
& +\sum_{i=1}^{n} \partial_{4 i} \Delta \ln M T R_{t-1}+\sum_{i=1}^{n} \partial_{5 i} \Delta \ln O P E N_{t-1} \\
& +\rho E T C_{t-1}+\varepsilon_{t}
\end{aligned}
$$

Symbol $\rho$ is the coefficient of the error correction term that tells us about the speed of convergence to the long-run equilibrium. To examine if the variables used in the model have long-run relationship, we test the combined null hypothesis of no cointegration against the alternative hypothesis that 
suggest the presence of cointegration. The null hypothesis for this test is tested by $\mathrm{H}_{0}: \lambda_{1}=\lambda_{2}=\lambda_{3}=\lambda_{4}=\lambda_{5}=0$ against the alternative hypothesis which is stated as $\mathrm{H}_{1}: \lambda_{1} \neq \lambda_{2} \neq \lambda_{3} \neq$ $\lambda_{4} \neq \lambda_{5} \neq 0$. The outcome of the F-statistics will determine the presence or otherwise of cointegration.

\section{EMPIRICAL FINDINGS INTERPRETATION}

AND

\subsection{Unit Root Test}

For a variable to be stationary, it must have a constant mean, variance, and constant autocovariances for each given lag. The Augmented-Dickey Fuller test is implemented to conclude whether the series is stationary or not.

ADF test indicates that all the variables are stationary at I(1). On the other hand, the KPSS suggests that LVST, LMTR and LOPEN are I(0) while LGDP and LMCP are
I(1) (Table 1). Meanwhile, since the KPSS is a more powerful test than the ADF, and none of the tests showed that any of the variables is $\mathrm{I}(2)$, we can proceed to the bounds testing procedure.

For a long-run relationship to exist among the variables, the F-statistic should be greater than both the upper critical bound (UCB) and the lower critical bound (LCB) at 5\% level of significance. If the F-statistic is lower than the (LCB), there is no cointegration. But if it lies between the (UCB) and (LCB), the test becomes inconclusive (Table 2). From the foregoing, since the F-statistic is higher than upper critical bound at 5\%, we can safely conclude that there is a long-run relationship.

From the results in Table 3, market capitalization, the value of shares traded, market turnover ratio, and the first and second lags of the aforementioned variables were statistically significant. The first lag of GDP and trade openness were not significant at $5 \%$ level. The implication here is that, a $1 \%$ increase in market capitalization, and market turnover ratio will lead to $0.63 \%$ and

Table 1. Unit Root Table Using ADF and KPSS

\begin{tabular}{lcccc}
\hline \multirow{2}{*}{ Variables } & LDF & KPSS & ADF & KPSS \\
\hline LGDP & -0.4608 & $0.7133^{* *}$ & $-5.5278^{* *}$ & $0.1224^{* *}$ \\
LMCP & -1.0189 & $0.5502^{* *}$ & $-5.2641^{* *}$ & 0.0884 \\
LVST & -0.8189 & $0.4471^{* *}$ & $-5.7431^{* *}$ & 0.1978 \\
LMTR & -2.0357 & $0.2921^{* *}$ & $-6.3996^{* *}$ & 0.1800 \\
LOPEN & -2.9056 & $0.4169^{* *}$ & $-6.6805^{* *}$ & 0.2879 \\
\hline The optimal lag order of the ADF test is chosen based on the Akaike Information Criterion. \\
** and * Indicate the significance at 1\% and 5\%, respectively.
\end{tabular}

Table 2. Bounds Test Results

\begin{tabular}{rccc}
\hline K=4 & \multicolumn{3}{c}{$\begin{array}{c}\text { Computed Wald Test (F-statistic): } \mathbf{6 . 8 9 4 1 0 6 .} \\
\text { Critical Values (Restricted Intercepts No Trend) }\end{array}$} \\
\hline \multirow{3}{*}{ Pesaran } & LCB & UCB & Significance \\
& 2.45 & 3.52 & $10 \%$ \\
\multirow{3}{*}{ Narayan } & 2.86 & 4.01 & $5 \%$ \\
& 3.74 & 5.06 & $1 \%$ \\
& 2.46 & 3.46 & $10 \%$ \\
& 2.94 & 4.08 & $5 \%$ \\
& 4.09 & 5.53 & $1 \%$ \\
\hline
\end{tabular}


$0.58 \%$ increase in GDP respectively. On the other hand, a $1 \%$ percent increase in the value of shares traded will reduce GDP by $0.6 \%$. Meaning the value of stock traded is having a negative impact on growth. This outcome is not in line with economic theory. This, to a large extent, could be attributed to various downturns in the stock market over the years. The stock market in Nigeria has been subject to both internal and external shocks; especial oil price shock. An important finding from the results in Table 4 is that, the inclusion of trade openness does not have any significant influence on the relationship between stock market development and economic growth in the short-run. The coefficient of determination is $80 \%$. By implication, about $80 \%$ of the variation in GDP is explained by the variables used in the model. This is a good fit. The error correction term is significant and rightly signed, which further confirms the presence of cointegration in the model. It shows the speed of adjustment to a long-run equilibrium from a shock in the short run. In this case, the speed of adjustment is relatively slow. It is about $6 \%$.

Table 4 shows the long-run relationship among the variables. In the long-run, apart from the constant term, openness to trade is the only variable with a significant impact on economic growth. The result exposes the fact that, the stock market in Nigeria cannot be relied on to promote growth in the long-run, but in the short-run, it cannot be ignored either. A one percentage increase in trade openness will increase economic growth by $12.3 \%$ in the long-run.

From the Block Exogeneity Wald Tests (Table 5), there exist a uni-directional relationship that flows from market capitalization, the value of stock traded and

Table 3. Short-run Dynamics using the ARDL Approach

\begin{tabular}{lccc}
\hline & Dependent Variable: LGDP $(2,3,3,3,1) *$ selected on the basis of AIC \\
\hline Variables & Coefficient & t-statistic & Probability \\
\hline$\Delta($ LGDP(-1) $)$ & -0.1904 & -1.2457 & 0.2297 \\
$\Delta($ LMCP $)$ & 0.6314 & 2.1475 & 0.0465 \\
$\Delta($ LMCP(-1) $)$ & 4.2382 & 2.4722 & 0.0243 \\
$\Delta($ LMCP(-2) & 4.4308 & 2.7788 & 0.0129 \\
$\Delta($ LVST $)$ & -0.6711 & -2.4305 & 0.0264 \\
$\Delta($ LVST(-1) $)$ & -4.2421 & -2.4606 & 0.0249 \\
$\Delta($ LVST(-2) $)$ & -4.6594 & -2.9240 & 0.0095 \\
$\Delta($ LMTR $)$ & 0.5876 & 2.0355 & 0.0577 \\
$\Delta($ LMTR(-1) & 4.2190 & 2.4261 & 0.0267 \\
$\Delta($ LMTR(-2) $)$ & 4.6498 & 2.8291 & 0.0116 \\
$\Delta($ LOPEN $)$ & 0.0093 & 0.4597 & 0.6515 \\
ECT(-1) & -0.0570 & -2.0764 & 0.0533 \\
$\mathrm{R}^{2}=0.8039$, AIC $=-0.9830$, SBC $=-0.2199$, F-stat. $=4.3561$, Durbin-Watson stat. $=1.8469$
\end{tabular}

Table 4. ARDL Long-run Relation

\begin{tabular}{lccc}
\hline \multicolumn{4}{c}{ Dependent Variable: LGDP } \\
\hline Variables & Coefficient & t-statistic & probability \\
\hline LMCP & -135.61 & -1.5167 & 0.1477 \\
LVST & 141.04 & 1.5573 & 0.1378 \\
LMTR & -146.76 & -1.5769 & 0.1332 \\
LOPEN & 12.340 & 2.5495 & 0.0207 \\
C & 705.408 & 427.39 & 0.1172 \\
\hline
\end{tabular}


market turnover ratio to economic growth without a feedback.

From Table 6, the model selected for this study was properly specified as reported by Ramsey RESET test. The model is also free from serial correlation and heteroscedasticity problems which is in line with OLS assumptions. This means that, the model for this study can be used for policy direction and forecast in relation to the stock market in Nigeria.

This is important in order to examine whether the above long and short-run relationships found are stable for the entire period of study. CUSUM test captured the systematic change, while CUSUMSQ restrained the departure of parameters from constancy. The graphs show the stability of the model for the sample drawn and indicated that the residuals are within 5\% critical bonds. This shows that all the coefficients in the ARDL model are stable.

\section{SUMMARY AND POLICY RECOMMENDATIONS}

The study examined the relationship between stock market development and economic growth in Nigeria in the period from 1980 to 2016. The bounds test suggests that the stock market development variables have a long-run relationship with economic growth. The Block Exogeneity Wald Tests

Table 5. Block Exogeneity Wald Tests Result

\begin{tabular}{lcc}
\hline & Dependent variable: LGDP \\
\hline Variables & Chi-square & Probability \\
\hline D(LMCP) & 20.4873 & 0.0000 \\
D(LVST) & 20.5126 & 0.0000 \\
D(LMTR) & 19.2241 & 0.0001 \\
D(LOPEN) & 1.28625 & 0.5256 \\
ALL & 50.0090 & 0.0000 \\
\hline
\end{tabular}

Table 6. Multivariate Residuals Diagnostics

\begin{tabular}{lcc}
\hline Test Statistics & \multicolumn{1}{c}{ LM test } & \multicolumn{1}{c}{ F-test } \\
\hline $\begin{array}{l}\text { Serial Correlation } \\
\text { Ramsey Reset }\end{array}$ & CHSQ $(1)=0.7589$ & $\mathrm{~F}(1,16)=0.0444[0.8357]$ \\
Heteroscedasticity & N/A & $\mathrm{F}(3,14)=2.6245[0.0914]$ \\
Normality & CHSQ $(1)=3.9207(0.9990)$ & $\mathrm{F}(16,17)=0.7632[0.7032]$ \\
\hline $\begin{array}{l}\text { These statistics are distributed as Chi-squared variates. The degrees of freedom in parentheses ( ) for LM test and the first figure } \\
\text { in the parenthesis for the F-test. Values in block parentheses [ ] are the probability values which are not significant at 5\% level. }\end{array}$
\end{tabular}
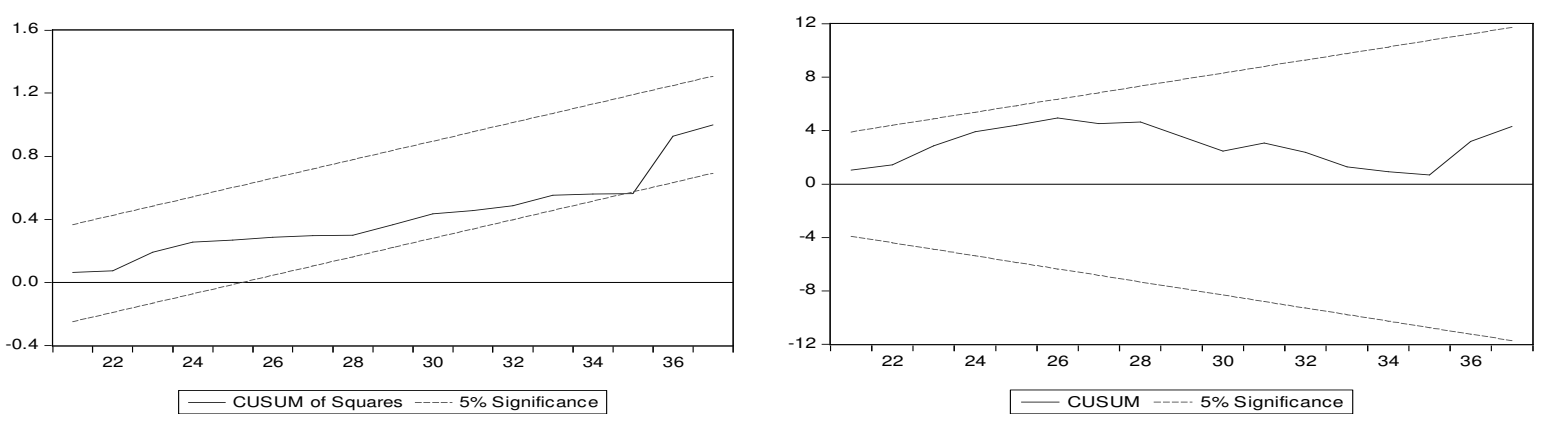

Figure 1. CUSUMSQ and CUSUM Plots for Stability Tests 
showed Granger causality flowing from market capitalization ratio, the value of stock traded ratio and market turnover ratio to economic growth without a feedback. From the results of the study, stock market capitalization ratio, the value of shares traded and market turnover ratio had a significant impact on economic growth, but the impact of the value of shares traded was negative. Since stock market development promotes economic growth, there is a need to nurture the stock market which will help to facilitate the increase and movement in capital for investment that will, in turn, accelerate growth. Also, since trade openness happened to be the only variable that impacts on economic growth in the long-run, it is also imperative for the government to provide the incentives that attract more foreign investment in trade, especially on trades that won't harm the environment.

The results of the findings also call for prudent monetary policy, stable macroeconomic environment, and tax reform which will encourage investors' efficient participation in stock market activities in Nigeria. Be that as it may, the outlook for Nigeria, in 2018, is relatively positive. According to the International Monetary Fund, the real GDP is expected to grow at $1.9 \%$ in 2018 . This, of course, represents a one percentage point increase from $0.8 \%$ in the previous year. The policy prescription necessitated from the findings of the study is for the regulatory authorities' to initiate policies that seems to promote stock market liquidity, stability and transparency which will indeed trickle down to economic growth in Nigeria. However, this can merely be achieved by ensuring an enabling macroeconomic environment in the country.

\section{References}

Adam, J.A., \& Sanni, I. (2005). Stock Market Development and Nigeria's Economic Growth. Journal of Economics and Allied Fields, 2 (2), 116-132.

Alajekwu, U.B., \& Achugbu, A.A. (2012). The role of stock market development on economic growth in Nigeria: A time series analysis. African Research Review, 6 (1), 51-70.

Alajekwu, U.B., Ezeabasili, V.N., \& Nzotta, S.M. (2013). Trade openness, stock market development and economic growth of Nigeria: Empirical evidence. Research Journal of Finance and Accounting, 4 (3), 120-127.

Anigbogu, U.E., \& Nduka, E.K. (2014). Stock market performance and economic growth: Evidence from Nigeria employing vector error correction model framework. The Economics and Finance Letters, 1 (9), 90-103.

Central Bank of Nigeria. (2017). Annual Statistical Bulletin. Retrieved from https://www.cbn.gov.ng/documents/Statbulle tin.asp

Donwa, P., \& Odia, J. (2010). An empirical analysis of the impact of the Nigerian capital market on her socioeconomic development. Journal of Social Sciences, 24 (2), 135-142.

Enekwe, C.I., Eziedo, K.N., \& Agu, C.I. (2016). Effect of Capital Market on Economic Growth in Nigeria. GOUNI Journal of Management and Social Sciences, 4 (1), 33-46.

Ewah, S.O., Esang, A.E., \& Bassey, J.U. (2009). Appraisal of capital market efficiency on economic growth in Nigeria. International Journal of Business and Management, 4 (12), 219-228.

Gazdar, K., \& Cherif, M. (2015). 


\title{
ДА ЛИ ФИНАНСИЈСКИ РАЗВОЈ ЗАСНОВАН НА ТРЖИШТУ АКЦИЈАМА ПОДСТИЧЕ ЕКОНОМСКИ РАСТ НА ТРЖИШТИМА У НАСТАЈАҢУ? НОВИ ДОКАЗИ ИЗ НИГЕРИЈЕ
}

\author{
Solomon Prince Nathaniel, Joseph Ayoola Omojolaibi and \\ Chikaodili Josephine Ezeh
}

\section{Извод}

Ова студија испитује утицај развоја тржишта акцијама на економски раст Нигерије. Студија обухвата период 1980-2016. Користи АРДЛ приступ коинтеграцији. Докази из студије показују да развој тржишта акција промовише економски раст на кратак рок, али дугорочно, утицај на развој тржишта акција није значајан. Утицај на раст тржишне капитализације, вредност тргованих акција и однос тржишног промета, су сви краткорочно значајни, док отвореност трговине није. У међувремену, трговинска отвореност је једина промењива која дугорочно значајно утиче на економски раст. Боунд тест за коинтеграцију открива дугорочан однос међу варијаблама. Све промењиве, осим отворености трговине, позитивно су повезане са економским растом. Резултати ове студије указују на то да развој тржишта акција игра велику улогу у економском расту Нигерије. Препоручује се да регулаторно тело донесе прописе који ће промовисати ликвидност, стабилност и одговорност на тржишту акција, што би могло да продужи економски раст Нигерије.

Кључне речи: развој тржишта акцијама, економски раст, анализа временских серија, блок егзогени Валдови тестови, АРДЛ

Institutions and the finance-growth nexus: Empirical evidence from MENA countries. Borsa Istanbul Review, 15 (3), 137-160.

Kajurová, V., \& Rozmahel, P. (2016). Stock market development and economic growth: Evidence from the European Union. Acta Universitatis Agriculturae et Silviculturae Mendelianae Brunensis, 64 (6), 1927-1936.

Magweva, R., \& Mashamba, T. (2016). Stock Market Development and Economic Growth: An Empirical Analysis of Zimbabwe (1989-2014). Financial Assets and Investing, 8 (3), 20-36.

Manasseh, C.O., Ogbuabor, J.E., Anumudu, C.N., Abada, F.C., Okolie, M.A., \& Okoro, O.E. (2018). The Causal Effect of Stock Market Development, Financial Sector Reforms and Economic Growth: The
Application of Vector Autoregressive and Error Correction Model. International Journal of Economics and Financial Issues, 8 (2), 357-369.

Ogunmuyiwa, M.S., \& Ekone, A.F. (2010). Money supply-Economic growth nexus in Nigeria. Journal of Social Sciences, 22 (3), 199-204.

Ogunrinola, I.I., \& Motilewa, D.B. (2015). Stock market liquidity and economic growth in Nigeria (1980 to 2012). Journal of Economics and International Business Management, 3(6).

Okonkwo, O.N., Ogwuru, H.O., \& Ajudua, E.I. (2014). Stock Market Performance and Economic Growth in Nigeria: An Empirical Appraisal. European Journal of Business and Management, 6 (26), 33-42. 
Okoro, C.O. (2017). Macroeconomic Factors and Stock Market Performance: Evidence from Nigeria. International Journal of Social Sciences and Humanities Review, 7 (1), 1-9.

Osuala, A.E., Okereke, J.E., \& Nwansi, G.U. (2013). Does Stock Market Development Promote Economic Growth In Emerging Markets? A Causality Evidence from Nigeria. World Review of Business Research, 3 (4), 1-13.

Owolabi, A., \& Ajayi, N.O. (2013). Econometrics analysis of impact of capital market on economic growth in Nigeria (1971-2010). Asian Economic and Financial Review, 3 (1), 99-110.

Pan, L., \& Mishra, V. (2018). Stock market development and economic growth: Empirical evidence from China. Economic Modelling, 68 (C), 661-673.

Pesaran, M.H., Shin, Y., \& Smith, R.J. (2001). Bounds testing approaches to the analysis of level relationships. Journal of Applied Econometrics, 16 (3), 289-326.

Pradhan, R.P., Arvin, M.B., Hall, J.H., \& Bahmani, S. (2014). Causal nexus between economic growth, banking sector development, stock market development, and other macroeconomic variables: The case of ASEAN countries. Review of Financial Economics, 23 (4), 155 -173. 